Penerbit:

Program Studi Magister Ilmu Kesehatan Masyarakat, Program Pascasarjana, Universitas Sam Ratulangi

Indonesian Journal of Public Health and Community Medicine is indexed by Google Scholar and licensed under a Creative Commons Attribution 4.0 International License.

\title{
Pelaksanaan Protokol Kesehatan Corona Virus Disease 2019 Oleh Masyarakat di Kabupaten Minahasa Tenggara
}

\author{
Oksfriani Jufri Sumampouw \\ Fakultas Kesehatan Masyarakat Universitas Sam Ratulangi \\ E-mail: oksfriani.sumampouw@unsrat.ac.id
}

\begin{abstract}
Abstrak
Latar Belakang: Pemerintah menetapkan berbagai kebijakan dalam rangka pengendalian penyebaran Corona Virus Disease 2019 (Covid-19). Namun upaya ini belum berjalan maksimal. Tujuan penelitian ini yaitu untuk menggambarkan pelaksanaan protokol kesehatan Covid-19 dalam pencegahan Covid-19 di Kabupaten Minahasa Tenggara. Metode Penelitian: Penelitian ini termasuk studi observasional dengan rancangan penelitian cross sectional study. Penelitian ini dilaksanakan di Kabupaten Minahasa Tenggara pada Agustus 2020. Subyek dalam penelitian ini yaitu 210 kepala keluarga keluarga yang memenuhi kriteria inklusi. Variabel penelitian ini yaitu pelaksanaan protokol kesehatan dalam upaya pencegahan Covid-19. Data hasil penelitian dianalisis secara univariat. Penyajian data dibuat dalam bentuk tabel dan narasi. Hasil Penelitian: Hasil penelitian ini menunjukkan bahwa masyarakat yang memiliki kebiasaan mencuci tangan sebesar 87,9\% (kategori tinggi), menggunakan masker sebesar 86,1\% (kategori tinggi) dan menjaga jarak sebesar 77,5\% (kategori tinggi). Kesimpulan: Kesimpulan penelitian ini yaitu masyarakat telah melakukan protokol kesehatan dengan baik. Namun perlu dilakukan upaya sosialisasi dan pengawasan secara terus menerus dan masif agar dapat menekan laju peningkatan Covid 19.
\end{abstract}

Kata Kunci: kebiasaan masyarakat; protokol kesehatan; Covid-19

\begin{abstract}
Background: The government has set various policies in order to control the spread of Corona Virus Disease 2019 (Covid-19). However, these efforts have not implemented optimally. The purpose of this study was to describe the health protocol implementation of the Covid-19 to prevention of Covid-19 in Southeast Minahasa Regency. Methode: This research was conducted in Southeast Minahasa Regency in August 2020. The subjects in this study were 210 family heads who met the inclusion criteria. The research variable is the implementation of health protocols in an effort to prevent Covid-19. The research data were analyzed by univariate. Presentation of data is made in table and narrative form. Result: This study showed that people who have the habit of washing hands are $87.9 \%$ (high category), using masks by $86.1 \%$ (high category) and keeping their distance by $77.5 \%$ (high category). Conclusion: The conclusion of this study is that the community has carried out the health protocol well. However, it is necessary to carry out continuous and massive socialization and monitoring efforts in order to reduce the rate of increase in Covid 19.

Key words: people's habit; health protocol; Covid-19
\end{abstract}




\section{PENDAHULUAN}

Mewabahnya virus Corona di awal tahun 2020 telah menjadi masalah kesehatan global. Virus Corona yang resmi dinamakan Covid-19 oleh World Health Organization (WHO), pertama kali ditemukan di Kota Wuhan, Provinsi Hubei, Cina. Setelah kejadian tersebut, persebaran virus Corona semakin meluas. Tercatat sudah ditemukan kasus persebaran virus tersebut di negara lain, seperti Singapura, Thailand, hingga negara lain termasuk Indonesia (WHO 2020, Anonim 2020).

Coronavirus merupakan keluarga besar virus yang umum di banyak spesies hewan yang berbeda, termasuk unta, sapi, kucing, dan kelelawar. Jarang, virus korona hewan dapat menginfeksi orang dan kemudian menyebar di antara orang-orang seperti dengan Middle East Respiratory Syndrome Coronavirus (MERS-CoV), SARS-CoV, dan sekarang dengan virus baru ini (bernama SARS-CoV-2). Virus SARS-CoV-2 yaitu Betacoronavirus, seperti MERS-CoV dan SARS-CoV. Ketiga virus ini berasal dari kelelawar. Urutan dari pasien AS mirip dengan urutan yang awalnya ditemukan di Cina yang menunjukkan kemungkinan munculnya varian baru-baru ini dari reservoir hewan. Awalnya, banyak pasien dalam wabah Covid-19 di Wuhan, Cina memiliki hubungan dengan makanan laut besar dan pasar hewan hidup, menunjukkan penyebaran dari hewan ke orang. Kemudian, semakin banyak pasien yang dilaporkan tidak memiliki paparan ke pasar hewan, menunjukkan penyebaran orang-ke-orang. Penyebaran orang ke orang telah dilaporkan di luar China, termasuk di Amerika Serikat dan lokasi lainnya (Parry, 2020; Griffits, 2020; Field, 2020).

Transmisi droplet respirasi merupakan rute utama penularan Covid-19. Selain itu, penyakit ini dapat ditularkan melalui droplet di udara dan kontak dengan pederita. Namun, kita juga harus mementingkan kasus asimptomatik, yang memainkan peran penting dalam proses penularan. Satu kali batuk dapat mengedarkan hingga 3.000 droplet. Droplet ini dapat mengenai orang lain, dan menutupi permukaan di sekitarnya, namun beberapa partikel kecil akan tetap berada di udara. Penelitian lainnya menemukan bahwa Coronavirus juga terdeteksi pada feses pasien yang dikonfirmasi di Wuhan, Shenzhen dan bahkan kasus pertama di Amerika Serikat, menunjukkan bahwa virus dapat berada dan bereplikasi di saluran pencernaan, yang menunjukkan kemungkinan penularan fecaloral, tetapi tidak yakin bahwa makan makanan yang terkontaminasi virus menyebabkan infeksi dan penularan. Ada juga pandangan bahwa virus dalam feses dapat ditransmisikan kembali melalui pembentukan aerosol dari droplet yang mengandung virus, yang membutuhkan penelitian lebih lanjut (Hafeez et al, 2020; Wu et al, 2020; Li et al, 2020).

Virus ini juga menyebar hingga ke feses, sehingga siapa pun yang tidak mencuci tangan dengan baik setelah menggunakan toilet, kamar mandi dapat mencemari apa pun yang disentuh seperti banyak virus pernapasan, termasuk flu. Covid-19 dapat menyebar melalui kontak dekat dengan droplet kecil yang dilepaskan dari sekresi saluran pernapasan atas individu yang terinfeksi, misalnya bersin, pilek atau batuk dari hidung dan mulut. Virus ini juga dapat ditularkan melalui kontaminasi permukaan ketika droplet ini mendarat di benda dan permukaan sekitar orang tersebut dan individu lain menyentuh benda atau permukaan ini dan selanjutnya menyentuh mata, hidung atau mulut dan kemudian orang-orang ini terinfeksi Covid-19. Selain itu, telah dilaporkan bahwa seorang ibu yang didiagnosis dengan pneumonia jenis coronavirus baru, dan bayinya positif untuk asam nukleat virus dalam swab faring setelah 30 jam kelahiran, menunjukkan bahwa jenis coronavirus ini dapat menyebabkan infeksi neonatal melalui penularan dari ibu ke anak, yang tentu saja perlu dikonfirmasi oleh penelitian yang lebih ilmiah (Hafeez et al, 2020; 
Wu et al, 2020; Li et al, 2020).

Data Covid-19 Kabupaten Minahasa Tenggara sampai 8 Agustus 2020 menunjukkan bahwa banyaknya pelaku perjalanan terdapat di kecamatan Touluaan yaitu 32 kasus, sedangkan suspek berada paling banyak di kecamatan Ratahan dengan dengan 10 kasus, sementara probable berada di Tombatu Utara dengan 2 kasus, dan kasus konfirmasi positif tertinggi didapati pada daerah Pasan dan Belang dengan 3 kasus.

Beberapa langkah pencegahan yang diajurkan untuk diterapkan di masyarakat diantaranya, membersihkan tangan menggunakan hand sanitizer atau sabun cuci tangan, menghindari menyentuh mata, hidung dan mulut, menutup hidung dan mulut dengan lengan atas bagian dalam atau tisu jika batuk atau bersin dan buang tisu bekas di tempat sampah, memakai masker medis jika memiliki gejala gangguan pernapasan dan melakukan kebersihan tangan setelah membuang masker, menjaga jarak minimal 1 meter dari orang yang mengalami gejala gangguan pernapasan. (Kemenkes RI, 2020). Tujuan penelitian ini yaitu untuk menggambarkan kebiasaan masyarakat dalam pelaksanaan protokol kesehatan dalam pencegahan penyebaran Covid-19 di Kabupaten Minahasa Tenggara.

\section{METODE PENELITIAN}

Penelitian ini merupakan studi observasional dengan rancangan penelitian crosssectional study. Penelitian ini dilakukan di Kabupaten Minahasa Tenggara pada 12-19 Agustus 2020. Subyek dalam penelitian ini yaitu masyarakat yang ada di Kabupaten Minahasa Tenggara. Berhubung saat ini masih ada pembatasan aktifitas masyarakat maka pengambilan data dilakukan secara dengan menerapkan protokol kesehatan yang ada. Berdasarkan hal tersebut maka metode penentuan subyek penelitian menggunakan metode purposif sampling dengan pertimbangan yaitu masyarakat yang bisa menerima dan bersedia diwawancarai oleh peneliti saat turun lapangan. Turun lapangan dilakukan selama 7 hari dan diperoleh sebanyak 210 kepala keluarga. Variabel dalam penelitian ini yaitu penerapan protokol kesehatan dengan indikator yaitu kebiasaan mencuci tangan, menggunakan masker dan menjaga jarak (social distancing). Instrumen penelitian menggunakan kuesioner yang telah divalidasi secara konstruk. Pertanyaan yang ditanyakan yaitu tentang kebiasaan masyarakat mencuci tangan, menggunakan masker dan menjaga jarak selama 7 hari terakhir. Data hasil penelitian dianalisis secara univariat. Penyajian data dibuat dalam bentuk tabel dan narasi.

\section{HASIL DAN PEMBAHASAN}

Pertanyaan yang diajukan terdiri atas 3 pertanyaan tentang kebiasaan masyarakat dalam upaya pencegahan Covid-19 seperti kebiasaan mencuci tangan, menggunakan masker dan menjaga jarak yang dilakukan dalam 7 hari terakhir sejak dilakukan wawancara. Pada kuesioner reponden yang menjawab diberi nilai 1 untuk (tidak pernah), 2 (hampir tidak pernah), 3 (jarang), 4 sering, 5 (selalu). Nilai tertinggi diperoleh dari 210 responden $\times 5=1050$ dan terendah diperoleh dari 210 responden $\times 1=210$. Interval yang didapat dari $1050-210=840$. Nilai ini dibagi dalam $100 \%$, sehingga dibuat kategori rendah $<50 \%=<630$, sedang $50-74 \%=630-840$, tinggi $>75 \%=>840$. Hal ini dapat dilihat pada Tabel 1. 
Tabel 1. Distribusi jawaban responden tentang kebijakan pemerintah

\begin{tabular}{clccc}
\hline No & Pertanyaan & Jumlah nilai & \% & Kategori \\
\hline $\mathbf{1}$ & Mencuci tangan & 948 & 87,9 & Tinggi \\
$\mathbf{2}$ & Menggunakan masker & 933 & 86,1 & Tinggi \\
$\mathbf{3}$ & Menjaga jarak & 861 & 77,5 & Tinggi \\
\hline
\end{tabular}

Tabel 1 menunjukkan bahwa pada waktu penelitian ini (12-19 Agustus 2020) masyarakat memiliki kebiasaan mencuci tangan sebesar 87,9\% (kategori tinggi), menggunakan masker sebesar $86,1 \%$ (kategori tinggi) dan menjaga jarak sebesar 77,5\% (kategori tinggi). Orang dapat tertular Covid-19 dari orang lain yang memiliki virus. Penyakit ini menyebar terutama dari orang ke orang melalui tetesan kecil dari hidung atau mulut, yang keluar saat penderita Covid-19 batuk, bersin, atau berbicara. Tetesan ini relatif berat, tidak bergerak jauh dan cepat tenggelam ke tanah. Orang dapat tertular Covid-19 jika mereka menghirup tetesan ini dari orang yang terinfeksi virus. Inilah mengapa penting untuk menjaga jarak setidaknya 1 meter dari orang lain. Tetesan ini dapat mendarat di objek dan permukaan di sekitar orang tersebut seperti meja, gagang pintu, dan pegangan tangan. Orang dapat terinfeksi dengan menyentuh benda atau permukaan ini, kemudian menyentuh mata, hidung, atau mulut mereka. Inilah mengapa penting untuk mencuci tangan secara teratur dengan sabun dan air atau membersihkan dengan antiseptik berbasis alkohol (WHO, 2020).

Sebuah studi Du et al, dalam Kemenkes (2020) melaporkan bahwa 12,6\% menunjukkan penularan presimptomatik. Penting untuk mengetahui periode presimptomatik karena memungkinkan virus menyebar melalui droplet atau kontak dengan benda yang terkontaminasi. Sebagai tambahan, bahwa terdapat kasus konfirmasi yang tidak bergejala (asimptomatik), meskipun risiko penularan sangat rendah akan tetapi masih ada kemungkinan kecil untuk terjadi penularan. Orang yang terinfeksi dapat langsung dapat menularkan sampai dengan 48 jam sebelum onset gejala (presimptomatik) dan sampai dengan 14 hari setelah onset gejala

Berdasarkan studi epidemiologi dan virologi saat ini membuktikan bahwa Covid19 terutama ditularkan dari orang yang bergejala (simptomatik) ke orang lain yang berada jarak dekat melalui droplet. Droplet merupakan partikel berisi air dengan diameter $>5-10$ $\mu \mathrm{m}$. Penularan droplet terjadi ketika seseorang berada pada jarak dekat (dalam 1 meter) dengan seseorang yang memiliki gejala pernapasan (misalnya, batuk atau bersin) sehingga droplet berisiko mengenai mukosa (mulut dan hidung) atau konjungtiva (mata). Penularan juga dapat terjadi melalui benda dan permukaan yang terkontaminasi droplet di sekitar orang yang terinfeksi. Oleh karena itu, penularan virus COVID-19 dapat terjadi melalui kontak langsung dengan orang yang terinfeksi dan kontak tidak langsung dengan permukaan atau benda yang digunakan pada orang yang terinfeksi misalnya, stetoskop atau termometer (Kemenkes RI, 2020).

Rekomendasi standar untuk mencegah penyebaran infeksi termasuk mencuci tangan secara teratur, menutupi mulut dan hidung ketika batuk dan bersin, memasak daging dan telur dengan matang sempurna. Hindari kontak dekat dengan siapa pun yang menunjukkan gejala penyakit pernapasan seperti batuk dan bersin (Gugus Tugas Percepatan Penanganan Covid-19, 2020). Tindakan pencegahan yang sederhana dapat dilakukan diantaranya (WHO 2020):

a. Bersihkan tangan secara teratur dan menyeluruh dengan antiseptik berbasis alkohol 
atau cuci dengan sabun dan air. Mencuci tangan dengan sabun dan air atau menggunakan antiseptik berbasis alkohol dapat membunuh virus.

b. Pertahankan jarak setidaknya 1 meter (3 kaki) dengan orang lain. Ketika seseorang batuk, bersin, atau berbicara, mereka menyemprotkan tetesan cairan kecil dari hidung atau mulut yang mungkin mengandung virus..

c. Hindari pergi ke tempat keramaian. Saat orang berkumpul dalam kerumunan, lebih mungkin melakukan kontak dekat dengan seseorang yang mengidap Covid-19 dan lebih sulit untuk menjaga jarak fisik 1 meter (3 kaki).

d. Pemerintah harus mendorong masyarakat umum untuk memakai masker kain jika terjadi penyebaran komunitas yang luas, dan terutama di mana jarak fisik tidak dapat dipertahankan. Masker adalah alat utama dalam pendekatan komprehensif untuk memerangi Covid-19.

e. Hindari menyentuh mata, hidung dan mulut. Tangan menyentuh banyak permukaan dan bisa terkena virus. Setelah terkontaminasi, tangan dapat memindahkan virus ke mata, hidung, atau mulut. Dari sana, virus bisa masuk ke tubuh dan menginfeksi.

f. Pastikan kita dan orang-orang di sekitar, mengikuti kebersihan pernapasan yang baik. Ini berarti menutupi mulut dan hidung dengan siku atau tisu yang tertekuk saat batuk atau bersin. Kemudian segera buang tisu bekas dan cuci tangana. Tetesan menyebarkan virus. Dengan mengikuti kebersihan pernapasan yang baik, kita melindungi orang-orang di sekitar dari virus seperti pilek, flu, dan Covid-19.

g. Tinggallah di rumah dan lakukan isolasi sendiri meski dengan gejala ringan seperti batuk, sakit kepala, demam ringan, hingga sembuh. Jika harus keluar rumah, kenakan masker agar tidak menulari orang lain. Menghindari kontak dengan orang lain akan melindungi mereka dari kemungkinan Covid-19 dan virus lainnya.

h. Jika kita mengalami demam, batuk dan kesulitan bernapas, dapatkan bantuan medis, tetapi hubungi melalui telepon terlebih dahulu jika memungkinkan dan ikuti arahan dari otoritas kesehatan setempat. Otoritas nasional dan lokal akan mendapatkan informasi terbaru tentang situasi di daerah setempat. Menelepon terlebih dahulu akan memungkinkan penyedia layanan kesehatan dengan cepat mengarahkan kita ke fasilitas kesehatan yang tepat. Ini juga akan melindungi dan membantu mencegah penyebaran virus dan infeksi lainnya.

i. Tetap up to date pada informasi terbaru dari sumber tepercaya, seperti WHO atau otoritas kesehatan lokal dan nasional. Otoritas lokal dan nasional paling baik ditempatkan untuk memberi nasihat tentang apa yang harus dilakukan orang-orang untuk melindungi diri mereka sendiri.

Penelitian dari Nikpouraghdamet et al (2020) tentang Covid-19 di Iran menunjukkan bahwa jenis kelamin laki-laki, usia yang lebih tua dan memiliki komorbiditas secara signifikan terkait dengan risiko kematian di antara pasien Covid-19. Oleh karena itu, penting untuk memberikan perhatian khusus pada pasien pria lansia dengan penyakit penyerta (komorbid) yang terkena Covid-19. Penelitian dari Chow et al (2020) tentang gambaran epidemiologi penderita Covid-19 di Amerika Serikat menunjukkan bahwa orang dengan kondisi kesehatan yang memiliki komorbid seperti diabetes mellitus, penyakit paru-paru kronis, dan penyakit kardiovaskular, memiliki risiko lebih tinggi untuk penyakit Covid-19 yang parah dibandingkan orang tanpa kondisi ini.

Penelitian dari Wang et al (2020) tentang gambaran epidemiologi dan klinis kasus Covid 19 menunjukkan bahwa epidemi Covid-19 menyebabkan lebih banyak infeksi dan kematian daripada SARS atau MERS, meskipun faktanya tingkat fatalitas kasus jauh 
lebih rendah. SARS-CoV-2 tampaknya lebih menular daripada SARS-CoV atau MERS$\mathrm{CoV}$ berdasarkan R0 nilai dihitung pada tahap awal wabah ini. Mayoritas orang yang terinfeksi tanpa gejala ringan dapat melepaskan virus dan menyebarkan virus ke orang lain, yang sangat menantang untuk mencegah penyebaran Covid-19. Oleh karena itu, pengawasan ketat sangat penting untuk mencegah penularan berkelanjutan. Intervensi aktif termasuk suplemen gizi, pengobatan simptomatik, dan pengobatan antivirus sangat penting untuk pasien ringan maupun pasien berat.

Selanjutnya penelitian dari Cheng et al (2020) tentang epidemiologi Covid-19 di Hongkong menunjukkan bahwa dari 413 petugas kesehatan yang merawat kasus-kasus Covid-19, sebanyak 11 petugas kesehatan $(2,7 \%)$ memiliki paparan tanpa pengaman yang membutuhkan karantina selama 14 hari tapi tidak ada yang terinfeksi. Selanjutnya, transmisi nosokomial SARS-CoV-2 tidak diperoleh. SARS-CoV-2 diidentifikasi dalam 1 dari 13 sampel lingkungan $(7,7 \%)$ tetapi tidak dalam 8 sampel udara yang dikumpulkan pada jarak $10 \mathrm{~cm}$ dari dagu pasien dengan atau tanpa memakai masker bedah.

Berdasarkan hasil-hasil penelitian diatas terlihat bahwa Covid-19 merupakan salah satu penyakit yang berbahaya karena penderita dapat berakhir dengan kematian jika memiliki penyakit penyerta (komorbid) dan tidak tertangani dengan baik. Oleh karena itu, upaya terbaik dalam pengendalian Covid-19 yaitu melalui tindakan preventif dengan memastikan agar virus tersebut tidak masuk ke tubuh. Tindakan yang paling efektif yaitu mencuci tangan, memakai masker dan menjaga jarak.

\section{PENUTUP}

Kesimpulan dari penelitian ini yaitu masyarakat di Kabupaten Minahasa Tenggara telah melakukan protokol kesehatan dengan baik dalam upaya pengendalian penyebaran Covid-19. Oleh karena itu, diharapkan agar pemerintah bisa melakukan upaya sosialisasi dan pengawasan yang lebih masif tentang upaya pencegahan Covid 19.

\section{REFERENSI}

Anonim. 2020. Undiagnosed pneumonia-China (HU) (01): wildlife sales, market closed, RFI Archive Number: 20200102.6866757. Pro-MED-mail. International Society for Infectious Diseases. Diakses tanggal 13 Januari 2020.

Cheng, V. C., S. C.Wong.,J. H.Chen.,C. C.Yip.,V. W.Chuang.,O. T.Tsang., ... \& K. Y. Yuen. 2020. Escalating infection control response to the rapidly evolving epidemiology of the Coronavirus disease 2019 (COVID-19) due to SARSCoV-2 in Hong Kong. Infection Control \& Hospital Epidemiology, 41(5), 493498.

Chow, N., K. Fleming-Dutra. R. Gierke., ... \& K. Roguski. 2020. Preliminary estimates of the prevalence of selected underlying health conditions among patients with coronavirus disease 2019-United States, February 12-March 28, 2020. Morbidity and Mortality Weekly Report, 69(13), 382.

Field, F. 2020. Nine dead as Chinese coronavirus spreads, despite efforts to contain it. The Washington Post. Diakses tanggal 22 Januari 2020.

Griffiths, J. 2020. Wuhan coronavirus death toll rises to nine with 440 infected says China, sparking fears of wider spread. CNN. Diakses tanggal 22 Januari 2020.

Gugus Tugas Percepatan Penanganan COVID-19. 2020. Peta Sebaran. (https://covid19.go.id/peta-sebaran, diakses tanggal 06 Juni 2020). 
Hafeez, A., A. Shmmon.,A. S.Sameera., A.Mumtaz and M. A. Shruti. 2020. Review of COVID-19 (Coronavirus Disease-2019): Diagnosis, Treatments and Prevention. EJMO 2020; 4(2):116-125

Kementerian Kesehatan RI. 2020. Mengenal Penyakit Infeksi Emerging (online) diakses dari http://infeksiemerging.kemkes.go.id/pengantar-infeksiemerging/\#.XldIO2gza00 pada 20 Februari 2020

Li, G., Y.Fan., Y.Lai., T.Han., Z.Li., and P.Zhou. 2020. Coronavirus infections and immune responses. J Med Virol. 2020; 92(4):424-32.

Li, H., S.Liu, Yu X, Tang S, Tang C. 2020. Coronavirus disease 2019 (COVID-19): Current status and future perspectives. International Journal of Antimicrobial Agents. https://doi.org/10.1016/j.ijantimicag.2020.105951

Nikpouraghdam, M. 2020. Epidemiological characteristics of coronavirus disease 2019 (COVID-19) patients in IRAN: A single center study. Journal of clinical virology: the official publication of the Pan American Society for Clinical Virology. 127(2020): 104378. doi: 10.1016/j.jcv.2020.104378

Parry, J. 2020. China coronavirus: cases surge as official admits human to human transmission. British Medical Journal. 368. doi: $10.1136 / \mathrm{bmj} . \mathrm{m} 236$. ISSN 1756-1833.

Wang, Y., Y.Wang., Y.Chen \& Q.Qin. 2020. Unique epidemiological and clinical features of the emerging 2019 novel coronavirus pneumonia (COVID-19) implicate special control measures. Journal of medical virology, 92(6), 568576.

WHO. 2020. Statement on the second meeting of the International Health Regulations (2005) Emergency Committee regarding the outbreak of novel coronavirus (2019-nCoV). Diakses dari https://www.who.int/news-room/detail/30-01-2020statement-on-the-second-meeting-of-the-international-health-regulations(2005)-emergency-committee-regarding-the-outbreak-of-novel-coronavirus(2019-ncov). pada 30 Januari 2020. Diakses tanggal 31 Januari 2020.

Wu, T., Q. Liuand Y. Z. Zhicong. 2020. The SARS-CoV-2 outbreak: What we know. International Journal of Infectious Diseases. 94 (2020): 44-48 